\title{
Effect of Potassium-induced Depolarization on Somatostatin Gene Expression in Cultured Fetal Rat Cerebrocortical Cells
}

\author{
Rosa Maria Tolón, ${ }^{1}$ Franco Sánchez Franco, ${ }^{2}$ Maria Teresa de los Frailes, ${ }^{1}$ Maria Jesús Lorenzo, ${ }^{1}$ and Lucinda \\ Cacicedo'
}

'Servicio de Endocrinologia, Hospital Ramón y Cajal and ²Centro Nacional de Investigaciones Clínicas, Instituto Carlos III, Madrid 28034, Spain

\begin{abstract}
The stimulatory effect of potassium depolarization upon somatostatin (SS) mRNA levels in primary cultures of fetal cerebrocortical cells was analyzed. Depolarizing stimuli, such as $56 \mathrm{mM} \mathrm{K}^{+}$exposure for $30 \mathrm{~min}$, elicited an increase in immunoreactive somatostatin (IR-SS) release to the media and decreased SS mRNA levels. These were increased when exposure to depolarization stimuli was prolonged up to 3 or more $\mathrm{hr}$. At this time, potassium (30 and $56 \mathrm{~mm}$ ) acted as a secretagogue, stimulating SS secretion, but was also effective in stimulating SS mRNA levels, suggesting that SS secretion can be coupled to SS mRNA accumulation. These changes were inhibited by the $\mathrm{Ca}^{2+}$ channel antagonist verapamil. In contrast, $\mathrm{Na}^{+}$channel blockade by TTX did not modify the $24 \mathrm{hr}$ potassium-induced increase in SS mRNA, although it partially abolished potassium-induced SS secretion. Examination of the rate of disappearance of SS mRNA levels after inhibition of mRNA transcription by actinomycin-D revealed that $\mathrm{K}^{+}$stimulation of cerebrocortical cells stabilized the SS mRNA. These results suggest that the induction of SS mRNA expression by $\mathrm{K}^{+}$is dose dependent, and involves the modulation of ion channels. The time-course study confirmed that the $\mathrm{K}^{+}$-induced SS mRNA accumulation is time dependent, chronic activation of the $\mathrm{Ca}^{2+}$ channels being necessary to stimulate SS gene expression. $\mathrm{K}^{+}$stimulation may also increase the level of SS mRNA in cerebrocortical cells by reducing its rate of degradation.
\end{abstract}

[Key words: somatostatin gene regulation, chronic depolarization, acute depolarization, potassium, potassium-induced somatostatin gene expression, brain somatostatin]

The neuropeptide somatostatin (SS) is widely distributed throughout the nervous system. In addition to its well-known role as a hypophysiotropic hormone, SS also appears to serve as a neurotransmitter or neuromodulator. SS release from neurons is, in turn, regulated by a number of classical neurotransmitters and neuropeptides (Arimura and Fishback, 1981; Reichlin, 1983).

\footnotetext{
Received April 27, 1993; revised July 22, 1993; accepted July 29, 1993.

We thank Dr. Richard Goodman for the rat SS cDNA clone. The technical assistance of Mrs. Constanza Navarro is gratefully acknowledged. We also thank Anna Steele and Mary Harper for the preparation of the manuscript. This work was supported by Grant PM 90-0030 from Ministerio de Educación y Ciencia.

Correspondence should be addressed to Lucinda Cacicedo, Servicio de Endocrinología, Hospital Ramón y Cajal, Carretera de Colmenar Km 9, 28034 Madrid, Spain.

Copyright (C) 1994 Society for Neuroscience $0270-6474 / 94 / 141053-07 \$ 05.00 / 0$
}

Secretion of SS is increased by numerous agents that stimulate adenyl cyclase activity, including vasoactive intestinal peptide (Robbins and Landon, 1985; Tapia-Arancibia and Reichlin, 1985), glucagon (Shimatsu et al., 1982), and epinephrine (Chihara et al., 1979), suggesting that cAMP is a second messenger for SS release. CAMP also regulates SS biosynthesis in primary cultures of fetal rat hypothalamic cells and in clonal isolates of NIH-3T3 fibroblast cells transfected with the rat SS gene (Montminy et al., 1986a). Further studies have demonstrated a sequence within the SS gene that is necessary for its transcriptional regulation by cAMP (Montminy et al., 1986b), and a great deal is known about the molecular mechanisms by which cAMP regulates neural SS gene expression.

The regulation of neuronal gene expression by membrane depolarization is well documented. Recent studies have shown that membrane depolarization causes not only rapid alterations in protein phosphorylation (Nairn et al., 1985), but also activation of new programs of gene expression in neuronal-type cells (Greenberg et al., 1985, 1986; Morgan and Curran, 1986; Black et al., 1987; Saffen et al., 1988; Bartel et al., 1989). Moreover, an increase in mRNA has been measured with stimuli causing the activation of $\mathrm{Ca}^{2+}$ and $\mathrm{Na}^{+}$channels and membrane depolarization (Loeffler et al., 1986; Morgan and Curran, 1986; Naranjo et al., 1986; Roach et al., 1987; Von Dreden et al., 1988). Genes regulated by depolarization include those that encode neuropeptides and neurotransmitter biosynthetic enzymes (Morris et al., 1988; Van Mguyen et al., 1990; Lu et al., 1991). Previous data from our laboratory (de los Frailes et al., 1990) demonstrated that when cultured cerebrocortical cells were exposed to high potassium concentrations for $24 \mathrm{hr}$, somatostatin release was not accompanied by intracellular depletion, suggesting an increment in its synthesis. Moreover, we also showed that chronic potassium treatment leads to posttranslational modifications of the peptide. Whether these changes in peptide synthesis reflect alterations in mRNA synthesis and/or processing, or whether they are also induced at the translational or posttranslational level is unknown.

To help define the mechanisms underlying depolarizationinduced changes in SS gene expression, the role of $\mathrm{Ca}^{2+}$ and $\mathrm{Na}^{+}$channels in SS mRNA induction by depolarization is examined in the present article. The possibility that $\mathrm{K}^{+}$might act at posttranscriptional level by altering SS mRNA stability is also investigated. We provide evidence suggesting that chronic depolarization induces increments on SS mRNA levels. This effect involves the activation of $\mathrm{Ca}^{2+}$ channels, and is partly produced by reducing the rate of degradation of its mRNA. 


\section{Materials and Methods}

Reagents. Tetrodotoxin (TTX), verapamil (VPM) and actinomycin-D were purchased from Sigma Chemical Co. (St. Louis, MO). Cyclic synthetic somatostatin (S-14) and $\mathrm{Tyr}^{1}-\mathrm{S}-14$ were obtained from Bachem, Inc.. (I a Jolla, CA). ${ }^{25} \mathrm{I}$ - and $\alpha-{ }^{32} \mathrm{P}-\mathrm{I}$ ITP were provided by New England Nuclear.

Buffers and media. Hank's Balanced Salt Solution (HBSS), phosphatebuffered saline (PBS), and Minimum Essential Medium (MEM) were obtained from M. A. Bioproducts (Walkersville, MD). MEM supplemented $\left(\mathrm{MEM}_{\mathrm{s}}\right)$ consisted of MEM containing 10\% fetal calf serum (FCS), 10\% horse serum (HS) (M. A. Bioproducts, Walkersville, MD), glucose $(6 \mathrm{~g} / \mathrm{l})$, insulin $(80 \mathrm{mU} / \mathrm{ml})$, streptomycin and penicillin $(100$ $\mathrm{U} / \mathrm{ml})$, and glutamine $(200 \mathrm{mg} / \mathrm{ml})$.

Cell culture. Preparation of primary long-term dispersed cell cultures of fetal rat cerebral cortex was done as previously described (de los Frailes et al., 1988). Timed pregnant Wistar rats were raised in our laboratory. On embryonic day 17 , the embryos were removed from the pentobarbital-anesthetized mothers. The cerebral cortices were dissected under sterile conditions and the cells mechanically dispersed. The cells were suspended in $\mathbf{M E M}_{s}$, plated in culture dishes at a density of $5 \times 10^{6}$ cells $/ 35 \mathrm{~mm}$ plate, and kept in a humidified atmosphere of $5 \%$ $\mathrm{CO}_{2}, 95 \%$ air at $37^{\circ} \mathrm{C}$. The medium was changed every $5-7 \mathrm{~d}$.

Depolarization studies. After 7-9 d in culture, media were removed and $1.5 \mathrm{ml}$ of fresh serum-free $\mathrm{MEM}_{\mathrm{s}}$, containing test substances (30 and $56 \mathrm{~mm} \mathrm{~K}^{+}, 20 \mu \mathrm{M}$ VPM, $1 \mu \mathrm{M}$ TTX), was added for different time periods. At the end of incubation, cells and media were processed and used for immunoreactive somatostatin (IR-SS) and SS mRNA determinations.

$m R N A$ stability studies. Actinomycin-D $(5 \mu \mathrm{g} / \mathrm{ml})$, known to prevent RNA synthesis (Dani et al., 1984), was added to cells $24 \mathrm{hr}$ after the addition of potassium (56 mM). Total RNA was extracted after $0,1,3$, 6,9 , and $24 \mathrm{hr}$ of incubation and analyzed by Northern blot.

Sample processing. At the termination of the experiments, the culture dishes were chilled on ice and $100 \mu 1$ of $1 N \mathrm{HCl}$ was added to $1.5 \mathrm{ml}$ of medium from the individual plates. Media were boiled for $5 \mathrm{~min}$ and spun down at $3000 \mathrm{rpm}$ for $60 \mathrm{~min}$, and the supernatants were kept frozen. The cells were scraped off into $1 \mathrm{ml} 0.1 \mathrm{~N} \mathrm{HCl}$ and extracted by sonication for $10 \mathrm{sec}$, followed by boiling $(5 \mathrm{~min})$ and centrifugation at $3000 \mathrm{rpm}$ for $60 \mathrm{~min}$. Supernatants of the media and cell extracts were kept at $-20^{\circ} \mathrm{C}$ until assayed.

Radioimmunoassay. Immunoreactive somatostatin (IR-SS) was determined by a well-characterized radioimmunoassay (Patel and Reichlin, 1978), using an antiserum against S-14 raised in our laboratory by immunizing rabbits with $\mathrm{S}-14$ bound to bovine thyroglobulin with glutaraldehyde. The initial dilution of the antiserum was $1: 30,000$ and the cross-reaction with S-28 was $20 \%$. Assay sensitivity was $10 \mathrm{pg} / \mathrm{ml}$. The intraassay and interassay variations were $8 \%$ and $15 \%$, respectively.

Extraction of RNA from primary cultures. Total RNA was extracted by a modification of the method described by Favaloro et al. (1980). Cells were washed with Ca-free Hank's solution and resuspended in 10 mM Tris (pH 7) $0.15 \mathrm{M} \mathrm{NaCl} / 2 \mathrm{mM} \mathrm{MgCl}_{2}$ containing $10 \mathrm{U}$ of RNAsin (Promega Biotech, Madison, WI). The cell suspension was treated with $0.5 \% \mathrm{NP}-40$ for $5 \mathrm{~min}$ at $0^{\circ} \mathrm{C}$ and the nuclear pellet and cytoplasm were separated by centrifugation $(14,000 \mathrm{rpm})$. The supernatant containing cytoplasmic RNA was added to an equal volume of $10 \mathrm{~mm}$ Tris $(\mathrm{pH}$ 7.6) $0.15 \mathrm{M} \mathrm{NaCl} / 5 \mathrm{~mm}$ EDTA and extracted with phenol : chloroform. RNA in the aqueous phase was precipitated by ethanol. The RNA pellet was dissolved in $2.3 \mathrm{M}$ ammonium acetate and precipitated by ethanol. The quality of the RNA was monitored by the ratio of UV absorbance at 260 and $280 \mathrm{~nm} . A_{260} / A_{280}$ ratios were consistently $1.95-2.0$, indicating that the samples were essentially free of contaminating protein.

Antisense RNA probe labeling. Levels of somatostatin mRNA were quantitated by Northern blot hybridization using an antisense somatostatin RNA probe. The antisense probe was constructed by inserting a fragment of the rat preprosomatostatin cDNA (Goodman et al., 1983) into the expression vector pSP 65 (Promega Biotech). The vector containing the somatostatin cDNA insert was linearized with SalI and a ${ }^{32}$ P-labeled antisense RNA probe produced with an SP6 polymerase. Labeled antisense somatostatin RNA probes were prepared according to the method recommended by the manufacturer (Boehringer Mannheim, Indianapolis, IN) using ${ }^{32} \mathrm{P}-\mathrm{UTP}(800 \mathrm{Ci} / \mathrm{mmol})$ as radionucleotide. The size of the radiolabeled riboprobe was confirmed by gel electrophoresis [ $1 \%$ agarose, formaldehyde/MOPS ( $20 \mathrm{~mm} 3$-[ $N$-morpholins]propane sulfonic acid, $5 \mathrm{~mm}$ sodium acetate, and $1 \mathrm{~mm}$ EDTA, ph
7.0)] followed by autoradiography. Transcription efficiency was assessed by trichloroacetic acid (TCA) precipitation onto Whatman GF/C paper followed by liquid scintillation counting. Efficiency ranged from $50 \%$ to $75 \%$.

Northern blot analysis. Ten micrograms of total RNA from each sample were desiccated in a Speed-Vac concentrator (Savant Instruments, farmingdale, NY) and reconstituted in $10 \mu \mathrm{l}$ of denaturing buffer composed of $50 \%$ deionized formamide, $16 \%$ formaldehyde, and $1 \times$ MOPS. RNA samples were then heated at $65^{\circ} \mathrm{C}$ for $15 \mathrm{~min}$, quickcooled, and loaded onto a $1 \%$ agarose-formaldehyde gel. Running buffer was $1 \times$ MOPS and $15 \%$ formaldehyde. After size separation, RNA samples were transferred to a Nytran membrane (Schleicher and Schuell, Keene, NH) at room temperature for $24 \mathrm{hr}$ in $1 \times \mathrm{TAE}(10 \mathrm{~mm}$ Tris $/ 5$ mM sodium acetate $/ 0.5 \mathrm{mM}$ EDTA).

Membranes were exposed to short-wave UV light $(0.12 \mathrm{~J})$ in a UV cross-linker (Hoefer Scientific Instruments, San Francisco, CA) and sequentially hybridized to ${ }^{32} \mathrm{P}$-labeled somatostatin antisense RNA probe. Blots were prehybridized for $2 \mathrm{hr}$ at $65^{\circ} \mathrm{C}$ in a solution containing $5 \times$ SSC $(1 \times$ SSC $=0.15 \mathrm{M}$ sodium chloride $/ 0.015 \mathrm{M}$ sodium citrate $), 50$ $\mathrm{mM} \mathrm{PO}_{4} \mathrm{pH} 6.5,10 \times$ Denhardt's $(1 \times$ Denhardt's $=0.02 \%$ Ficoll $-400 /$ $0.02 \%$ BSA $/ 0.02 \%$ polyvinylpyrrolidone- 40 ), $50 \%$ deionized formamide, and $500 \mu \mathrm{g} / \mathrm{ml}$ denatured salmon sperm DNA. Hybridization was performed for $24 \mathrm{hr}$ at $65^{\circ} \mathrm{C}$ in the same buffer, after adding $4 \times 10^{6}$ $\mathrm{cpm} / \mathrm{ml}$ labeled probe.

After hybridization, the blots were washed twice for $30 \mathrm{~min}$ in $2 \times$ $\mathrm{SSC}, 0.1 \% \mathrm{SDS}, 65^{\circ} \mathrm{C}$, and twice for $30 \mathrm{~min}$ in $0.2 \times \mathrm{SSC}, 0.1 \% \mathrm{SDS}$. Autoradiograms were developed after exposure to $\mathrm{x}$-ray film for $10 \mathrm{hr}$ at $-80^{\circ} \mathrm{C}$ using two intensifying screens.

To ensure that equal amounts of RNA were loaded and the transfer was quantitative, RNAs were stained with methylene blue after transfer from agarose/formaldehyde gels to nylon membrane (Herrin and Schmidt, 1988).

Statistical analysis of the data was done using the Student's $t$ test.

\section{Results}

\section{Effect of acute depolarization by potassium}

The potential role of membrane depolarization was assessed by incubating fetal cerebrocortical cells kept in culture for $8 \mathrm{~d}$ with high potassium concentrations ( $56 \mathrm{~mm}$ ) for $30 \mathrm{~min}$. In some cases, agents blocking the sodium (TTX) or calcium (VPM) ion channels were simultaneously added. Cell exposure to $56 \mathrm{~mm}$ potassium in the presence of $2.2 \mathrm{~mm}$ calcium resulted in a significant stimulation of IR-SS release (Fig. 1). This effect was completely prevented by the addition of VPM and partially abolished by TTX (Fig. 1). Northern blot hybridization assays were performed to determine whether the increase caused by $56 \mathrm{~mm}$ potassium was associated with an increase in SS mRNA accumulation. Potassium decreased SS mRNA accumulation (Fig. 2). Block of calcium and sodium entry with VPM and TTX reversed potassium-induced SS mRNA decrease, suggesting that voltage-dependent $\mathrm{Ca}^{2+}$ and $\mathrm{Na}^{+}$channels are involved in the potassium-induced decrease in SS mRNA accumulation.

\section{Effect of chronic depolarization by potassium}

Figure 3 shows the effect of chronic potassium depolarization on IR-SS in the presence of drugs that modulate $\mathrm{Na}^{+}$and $\mathrm{Ca}^{2+}$ channels. Exposure to $56 \mathrm{mM} \mathrm{K}^{+}$for $24 \mathrm{hr}$ resulted in a significant stimulation of IR-SS release. This effect was calcium dependent, since it was partially abolished by $20 \mu \mathrm{M}$ VPM. On the contrary, TTX $(1 \mu \mathrm{M})$ addition did not prevent potassium stimulatory effect, possibly because $\mathrm{Na}^{+}$entry is not an absolute requirement for chronic $\mathrm{K}^{+}$-induced $\mathrm{SS}$ secretion. Intracellular IR-SS content was increased by $\mathrm{K}^{+}$treatment; thus, total IRSS content was increased, suggesting an increment in its synthesis. Neither VPM nor TTX alone modified basal SS release. As opposed to acute depolarization, chronic exposure to elevated concentrations of potassium elicited a very large increase 


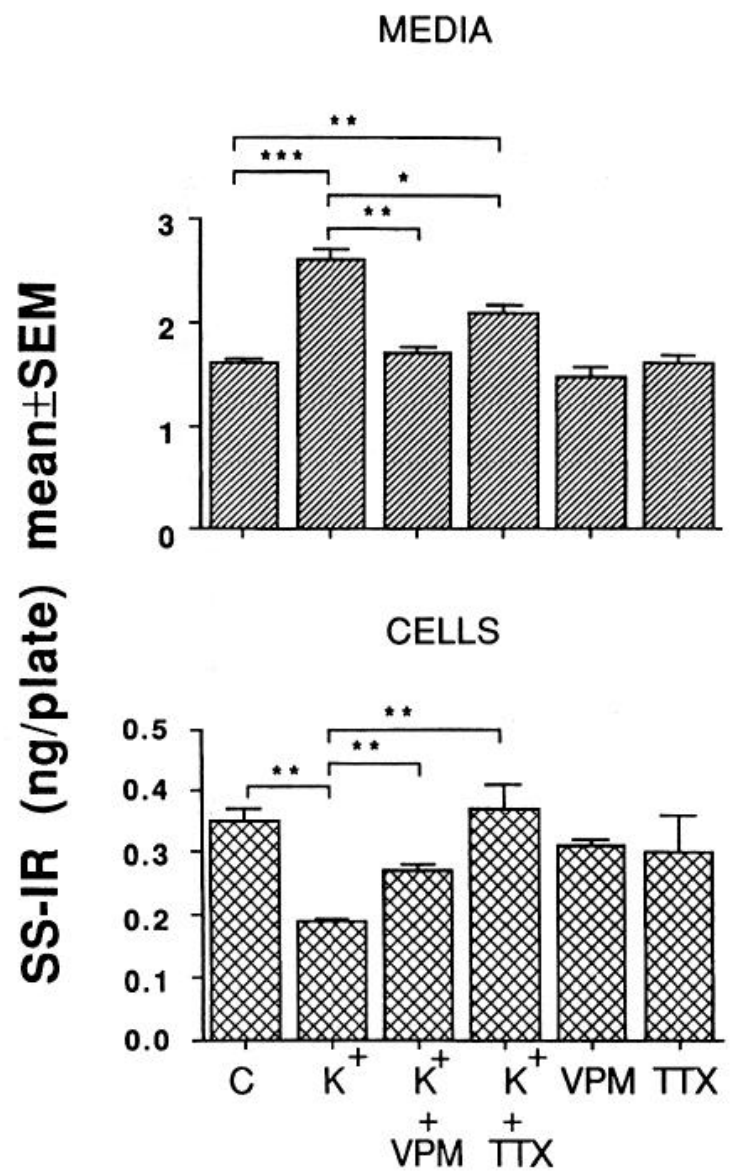

Figure 1. Effect of acute potassium depolarization on IR-SS release (upper panel) and cell content (lower panel) in cultured cerebrocortical cells. Cells were obtained from 17-d-old fetuses and maintained in culture for 7-10 d. Cultures were exposed to $56 \mathrm{~mm} \mathrm{~K}^{+}$alone or combined with $20 \mu \mathrm{M}$ verapamil (VPM) or $1 \mu \mathrm{M}$ tetrodotoxin (TTX). Control $(C)$ received MEM alone. The values represent the mean \pm SEM of IR-SS $(n=4) .{ }^{* * *}, p<0.001 ;{ }^{* *}, p<0.01 ;{ }^{*}, p<0.05$.

in SS mRNA accumulation (Fig. 4). In addition, mRNA stimulation was blocked by VPM (Fig. 4), indicating that the potassium effect was, indeed, mediated by voltage-dependent calcium channels. TTX showed no modulating effect (Fig. 4), reflecting that the voltage-dependent $\mathrm{Na}^{+}$channels are not involved in the chronic potassium-induced SS mRNA accumulation. VPM and TTX did not affect the basal level of SS gene expression. This indicates that, when at rest, extracellular $\mathrm{Ca}^{2+}$ and $\mathrm{Na}^{+}$and/or their voltage-dependent channels by themselves are probably not involved in regulating basal SS mRNA.

\section{Dose response experiments}

To confirm the action of chronic exposure to $\mathrm{K}^{+}$on SS mRNA levels, cells were incubated with two different $\mathrm{K}^{+}$concentrations for $24 \mathrm{hr}$. The Northern blot on Figure 5 shows that even at concentrations of $30 \mathrm{~mm} \mathrm{~K}^{+}$, SS mRNA levels were increased, and that this effect was higher in the presence of $56 \mathrm{mM} \mathrm{K}^{+}$. This study reveals a clear dose-dependent response of the SS mRNA levels to $\mathrm{K}^{+}$treatment.

\section{Time course of potassium effect}

Incubation of the cells with potassium ( $56 \mathrm{~mm}$ ) for up to $24 \mathrm{hr}$ resulted in an increase in media IR-SS content (Fig. 6), at 30 min and $24 \mathrm{hr}$, whereas cell IR-SS content remained below that

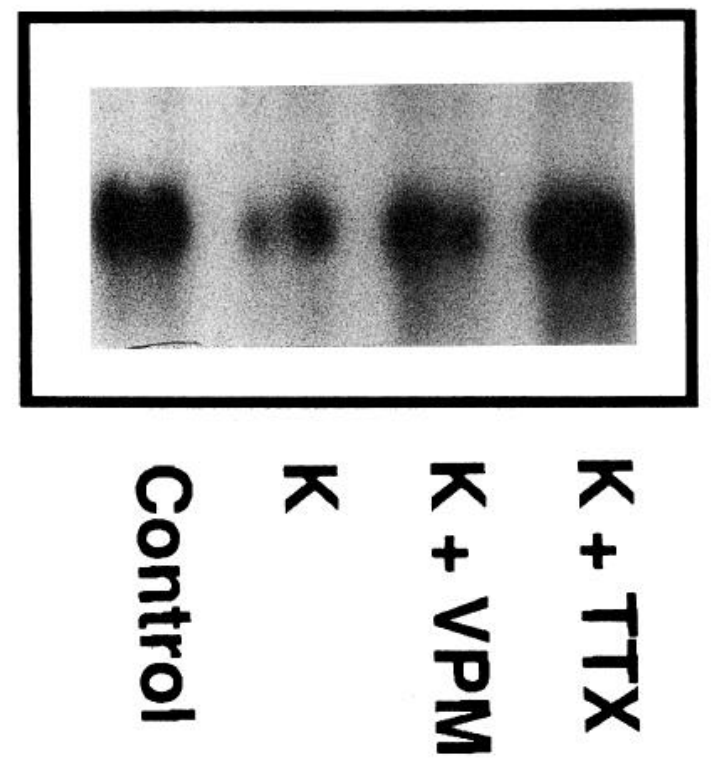

Figure 2. SS mRNA accumulation in primary cultures of cerebrocortical cells: Northern blot analysis of total RNA extracted from cultures incubated for $30 \mathrm{~min}$ with $56 \mathrm{~mm} \mathrm{~K} \mathrm{~K}^{+}$alone or combined with VPM $(20 \mu \mathrm{M})$, and/or TTX $(1 \mu \mathrm{M})$. Control received MEM alone. Each lane contained $10 \mu \mathrm{g}$ total cellular RNA. Blots were hybridized to a ${ }^{32} \mathrm{P}$ labeled SS antisense RNA probe.

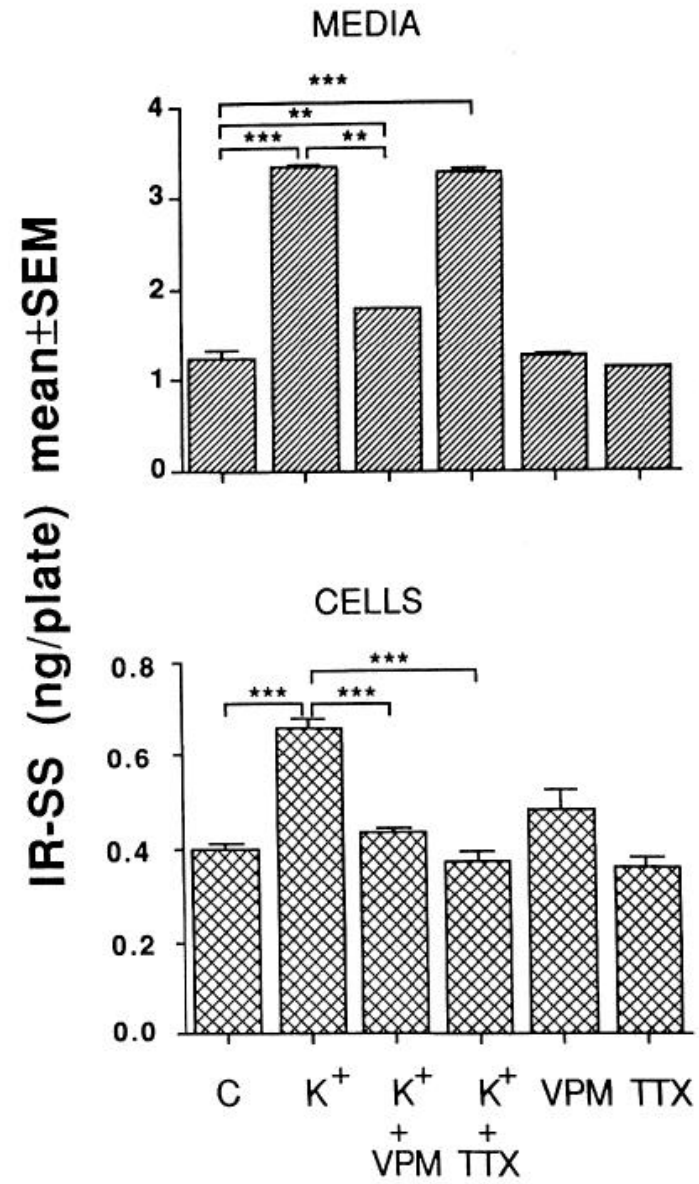

Figure 3. Effect of chronic potassium depolarization on IR-SS release (upper panel) and cell content (lower panel) in cultured cerebrocortical cells. Cells obtained from 17-d-old fetuses and maintained in culture for 7-10 d were incubated for $24 \mathrm{hr}$ with $56 \mathrm{~mm} \mathrm{~K}^{+}$and/or VPM (20 $\mu \mathrm{M})$, and/or TTX $(1 \mu \mathrm{M})$. C (control). The values represent the mean \pm $\operatorname{SEM}(n=4) .{ }^{* * *}, p<0.001 ;{ }^{* *}, p<0.01$. 

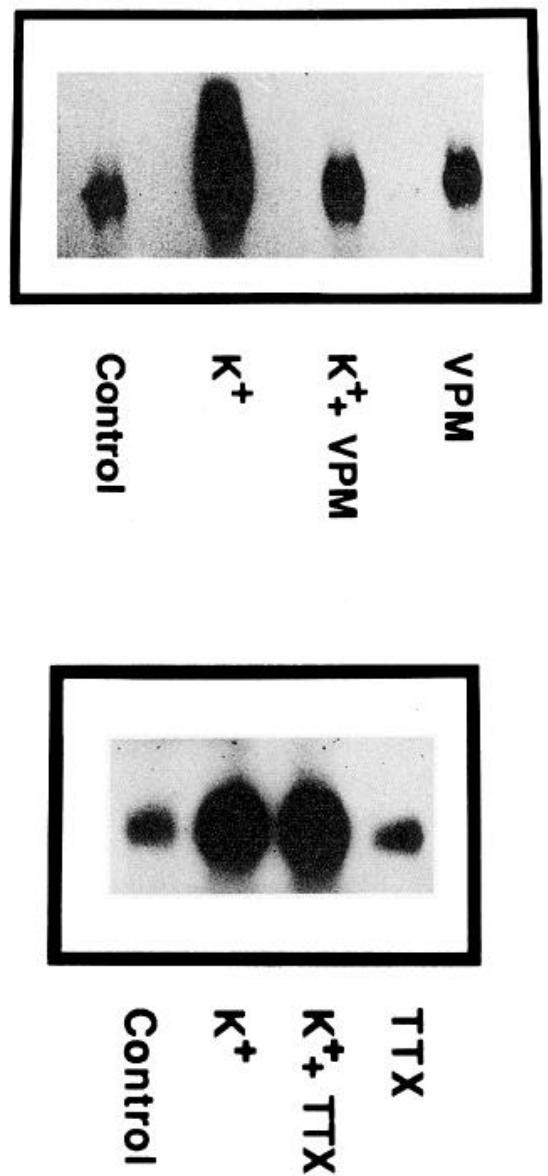

Figure 4. Stimulation of SS mRNA accumulation in primary cultures of cerebrocortical cells: autoradiogram of a Northern blot containing cerebrocortical cell cytoplasmic RNA hybridized to a ${ }^{32} \mathrm{P}$-labeled SS antisense RNA probe. Cells were exposed to $56 \mathrm{mM} \mathrm{KCl}\left(\mathrm{K}^{+}\right)$, and/or VPM $(20 \mu \mathrm{M})$, and/or TTX $(1 \mu \mathrm{M})$ for $24 \mathrm{hr}$. $C$, control (each lane contained $10 \mu \mathrm{g}$ total cellular RNA). Top, Influence of calcium channel blocker verapamil (VPM). Bottom, Influence of sodium channel blocker tetrodotoxin (TTX).

of control at all times tested, except at $24 \mathrm{hr}$. When SS mRNA was measured for the same time period, it was decreased at the earliest time tested $(30 \mathrm{~min})$, and a progressive increase was observed after $3 \mathrm{hr}$ (Fig. 7).

\section{Effect of potassium on somatostatin mRNA stability}

In order to study whether potassium may influence SS mRNA half-life, we carried out actinomycin-D decay curves in control cells and in $\mathrm{K}^{+}$-treated cells. Cells were removed 0, 1, 3, 6, 9, and $24 \mathrm{hr}$ after actinomycin-D addition. Total RNA was extracted and analyzed by Northern blot. As is shown in Figure 8 , potassium stimulation of cerebrocortical cells clearly reduced the rate of disappearance of SS mRNA.

\section{Discussion}

The present work provides evidence that chronic membrane depolarization, elicited by elevated extracellular $\mathrm{K}^{+}$concentrations, increased the level of SS mRNA. In agreement with previous data, we have observed that acute $(30 \mathrm{~min})$ stimulation by depolarizing concentrations of potassium leads to an increase in SS peptide release (Mudge et al., 1977; Patel et al., 1977; Wakabayashi et al., 1977; Berelowitz et al., 1978; Iversen et al.,
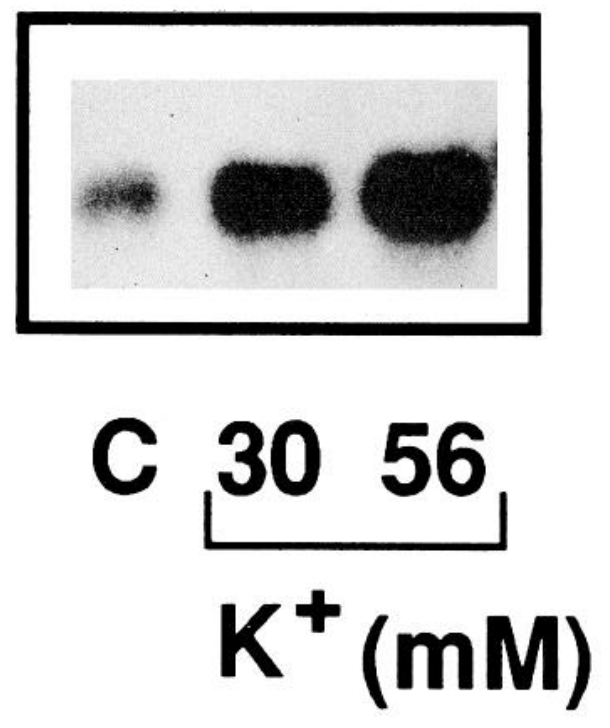

Figure 5. Dose-response effects of $\mathrm{K}^{+}$on SS mRNA levels: Northern blot analysis of total RNA extracted from control $(C)$, and cerebrocortical cells treated with 30 and $56 \mathrm{~mm} \mathrm{KCl}$ for $24 \mathrm{hr}$. Each lane contained $10 \mu \mathrm{g}$ total cellular RNA. Blots were hybridized to a ${ }^{32} \mathrm{P}$ labeled SS antisense RNA probe.

1978; Maeda and Frohman, 1980; Bonanno et al., 1991), along with a decrease in SS mRNA. From our results, it is evident that with short potassium treatment there is some dissociation between the accumulation of SS peptide and SS mRNA. In fact,

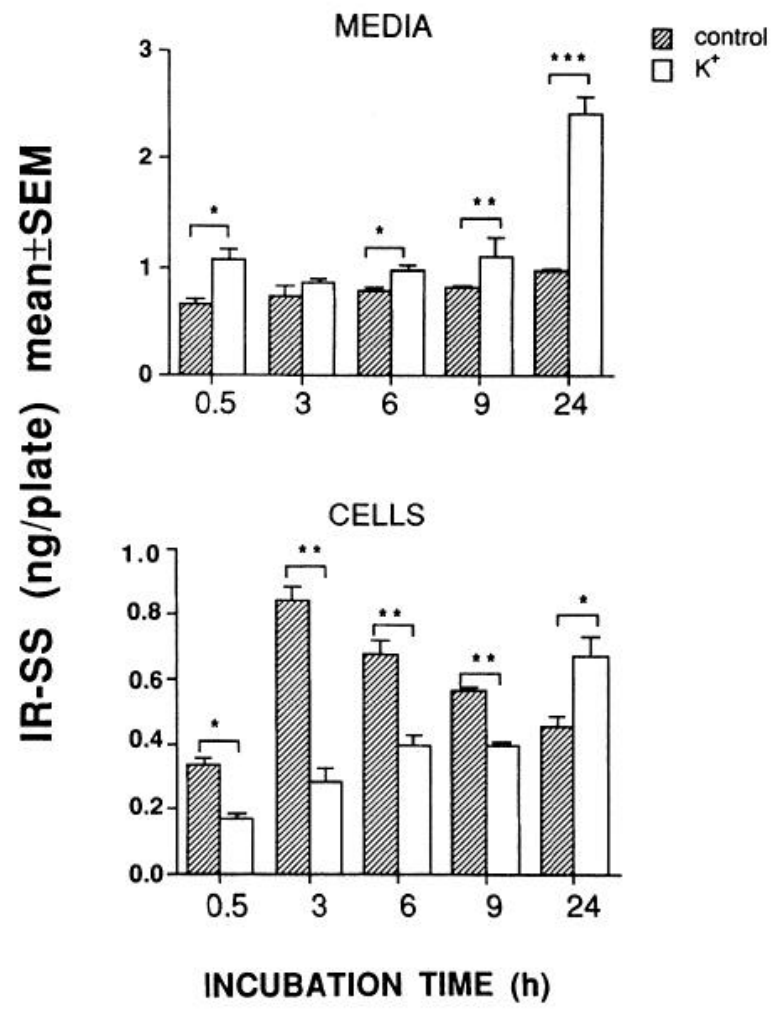

Figure 6. Time course of the effect of high potassium concentrations on IR-SS release (upper panel) and cell content (lower panel) in cerebrocortical cultures. Cells were incubated with $56 \mathrm{mM} \mathrm{K}^{+}$or MEM alone (control) for up to $24 \mathrm{hr}$. The values represent the mean \pm SEM of IR-SS $(n=4)$. $C$, control. ${ }^{* * *}, p<0.001 ;{ }^{* *}, p<0.01 ;{ }^{*}, p<0.05$. 


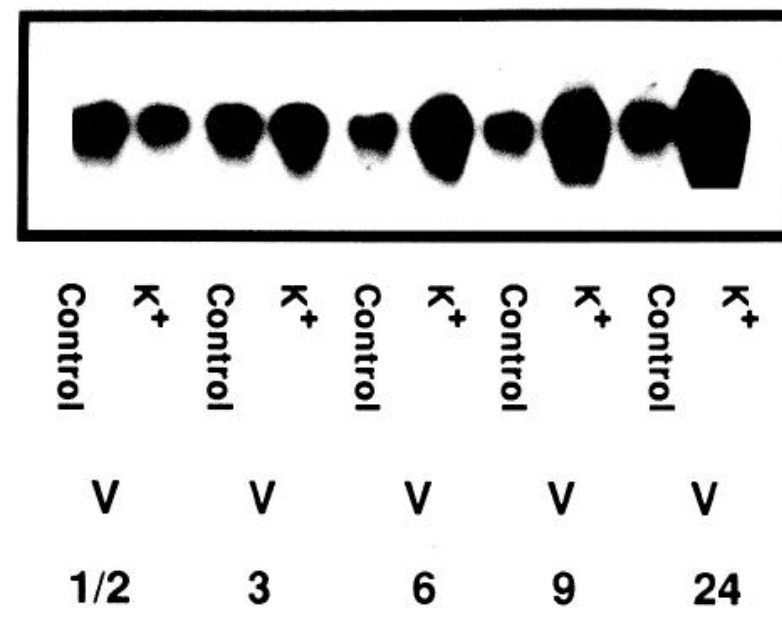

INCUBATION TIME (h)

Figure 7. Time dependence of SS mRNA accumulation in primary cultures of cerebrocortical cells treated with $56 \mathrm{~mm} \mathrm{KCl}$. Cells were incubated with $56 \mathrm{~mm} \mathrm{~K}^{+}\left(\mathrm{K}^{+}\right)$or MEM alone (Control) for up to 24 hr. This autoradiogram of a Northern blot depicts the amount of hybridizable SS mRNA. Ten micrograms of total cellular RNA from each sample were electrophoresed, blotted, and hybridized with a ${ }^{32} \mathrm{P}$-labeled SS antisense RNA probe.

we observed that a $30 \mathrm{~min}$ exposure to $\mathrm{K}^{+}$leads to a high increment in the concentration of medium SS, along with a decrease of the intracellular content. When the amount of SS in both compartments is summed, it is higher in the $\mathrm{K}^{+}$-treated plates than in the control plates, suggesting that an increase in the translation activity has taken place. To explain the controversy between reduced SS mRNA and higher IR-SS levels, several mechanisms could be suggested; for example, short-term $\mathrm{K}^{+}$exposure could decrease SS mRNA stability; SS transcription induced by $\mathrm{K}^{+}$could be delayed with respect to SS translation. Although there is not evidence in the literature supporting these hypothesis, these or other mechanisms could account for the dissociation between the activation of SS translation and transcription that occurs at $30 \mathrm{~min}$. Moreover, previous data from our laboratory (de los Frailes et al., 1990) demonstrated that potassium treatment modified the forms of SS released, causing an increase in high-molecular-weight forms, indicating modification in the processing of SS. Based on these data, we could hypothesize that the effects observed on SS peptide, after acute exposure, could reflect posttranslational mod- ification of the peptide and/or variations in the translational activity. In the present study, the $\mathrm{K}^{+}$-induced increase in SS release was almost completely blocked by VPM and TTX, indicating that the $\mathrm{Ca}^{2+}$ and $\mathrm{Na}^{+}$entry through voltage-dependent $\mathrm{Ca}^{2+}$ and $\mathrm{Na}^{+}$channels is a requirement for these responses. Therefore, these results suggest that in cultured cerebrocortical cells, $\mathrm{Ca}^{2+}$ and $\mathrm{Na}^{+}$entry through voltage-dependent $\mathrm{Ca}^{2+}$ and $\mathrm{Na}^{+}$channels is an adequate and sufficient event to produce an increase in acute somatostatin release.

We have previously demonstrated, using media and cell levels of IR-SS as indices of SS biosynthesis (de los Frailes et al., 1989), that chronic exposure of cultured cerebrocortical cells to high potassium concentrations increased SS biosynthesis. The present data demonstrate that chronic $\mathrm{K}^{+}$-induced depolarization also induces an increment in SS mRNA accumulation. As shown in the time-course study, the effect of $\mathrm{K}^{+}$is time dependent, and requires between 3 and $6 \mathrm{hr}$ to show up. This time dependence could explain the discrepancy with the data published by Montminy (1986a), which showed that treatment of the diencephalic cells with $30 \mathrm{~mm} \mathrm{KCl}$ for $4 \mathrm{hr}$ diminished SS mRNA accumulation.

We have found that depolarization-induced mRNA is almost inhibited by the calcium channel blocker VPM, which is consistent with calcium being the effector of the transcriptional response to depolarization. These data are in agreement with previous reports describing that the calcium channel antagonist $\mathrm{D}_{600}, \mathrm{VPM}$, and $\mathrm{Co}^{2+}$ (Kley et al., 1986) or low calcium media (Waschek et al., 1987; Morris et al., 1988; Sheng et al., 1990; $\mathrm{Lu}$ et al., 1991) inhibit veratridine- or $\mathrm{KCl}$-induced activation of proenkephalin gene expression in bovine adrenal chromaffin cells. They further support the hypothesis that one of the biological roles of voltage-sensitive calcium channels located in neuronal cell bodies may be the transduction of depolarizing signals to the nucleus to regulate gene expression. Alterations in intracellular calcium levels activate several transduction pathways, resulting in distinct patterns of gene expression. Many responses to a $\mathrm{Ca}^{2+}$-mediated agonist involve interaction with calmodulin and subsequent activation of calcium-dependent protein kinases (Dash et al., 1991; Sheng et al., 1991). In addition, in many cell types, the $\mathrm{Ca}^{2+}$ pathway of agonist action interacts synergistically with the diacylglycerol pathway (Nishizuka, 1984). This study opens up the possibility that one of these intracellular pathways may be involved in potassiuminduced SS gene expression. None of the $\mathrm{Ca}^{2+}$ and $\mathrm{Na}^{+}$channelblocking drugs had a significant effect on the basal level of SS mRNA and IR-SS. This indicates that, in the resting state, extracellular $\mathrm{Ca}^{2+}$ and $\mathrm{Na}^{+}$and/or the $\mathrm{Ca}^{2+}$ and $\mathrm{Na}^{+}$channels

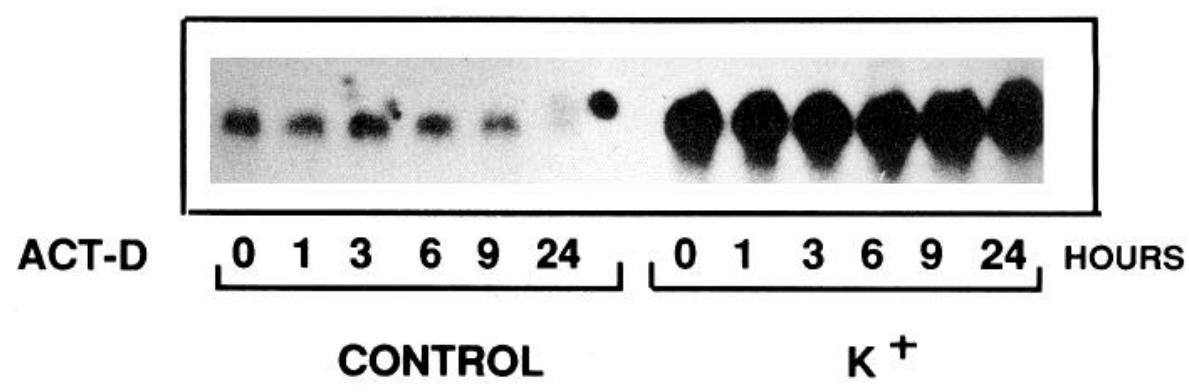

Figure 8. Actinomycin-D decay curves: Northern blot analysis of total RNA extracted from control and $\mathrm{K}^{+}$-treated cells (for $1,3,6,9$, and 24 $\mathrm{hr}$ ) after addition of actinomycin-D $(5 \mu \mathrm{g} / \mathrm{ml})$ at time $24 \mathrm{hr}$. Each lane contained $10 \mu \mathrm{g}$ total cellular RNA. Blots were hybridized to a ${ }^{32} \mathrm{P}$-labeled SS antisense RNA probe. 
themselves are probably not involved in regulating basal mRNA levels and secretion.

It was observed that VPM does not completely inhibit the increase of SS mRNA induced by depolarization. This could be due to the action of potassium stimulation on the steady-state levels of SS mRNA, reducing the rate of degradation of SS mRNA. The molecular mechanisms accounting for the $\mathrm{K}^{+}$mediated regulation of $\mathrm{mRNA}$ stability are unknown. However, it could be possible that $\mathrm{K}^{+}$induces the synthesis of a new protein through transcriptional activation of its gene. This protein then directly or indirectly interacts with SS mRNA, increasing its stability. There is evidence that other hormones, such as prolactin (PRL) (Guyette et al., 1979; Eisenstein and Rosend, 1988), estrogen (Brock and Shapiro, 1983), glucocorticoids (Vannice et al., 1984), and thyroid hormone (Simonet and Ness, 1989) may induce some of their actions by stabilizing certain mRNA species.

As our cultures are based on a mixed cell system, we have to consider that all the effects evoked by $\mathrm{K}^{+}$-induced depolarization can be attributed not only to a direct action on somatostatinergic neurons but also to the release by other cell types of a secondary effector acting on these SS neurons.

In summary, the data presented here demonstrate that in fetal neuronal cells chronic $\mathrm{K}^{+}$-induced depolarization activates SS gene expression through a calcium-dependent pathway and, at least in part, by increasing the stability of the SS mRNA.

\section{References}

Arimura A, Fishback (1981) Somatostatin regulation and secretion. Neuroendocrinology 33:246-256.

Bartel DP, Sheng M, Lau LF, Greenberg ME (1989) Growth factors and membrane depolarization activate distinct programs of early response gene expression: dissociation of fos and jun induction. Genes Dev 3:304-313.

Berelowitz M, Kronheim S, Pimstone BL, Sheppard M (1978) Potassium stimulated calcium dependent release of immunoreactive somatostatin from incubated rat hypothalamus. J Neurochem 31:15371539.

Black IB, Adler JE, Dreyfus CF, Friedman WF, LaGamma EF, Roach AH (1987) Biochemistry of information storage in the nervous system. Science 236:1263-1268.

Bonanno G, Parodi B, Cafaggi S, Raiteri M (1991) Somatostatin release from rat cerebral cortex synaptosomes. J Neurochem 57:12581264.

Brock ML, Shapiro DJ (1983) Estrogen stabilizes vitellogenin mRNA against cytoplasmic degradation. Cell 34:207-213.

Chihara K, Arimura A, Schally AV (1979) Effect of intraventricular injection of dopamine, norepincphrinc, acctylcholine, and 5-hydroxytryptamine on immunoreactive somatostatin release into rat hypophyseal portal blood. Endocrinology 104:1656-1662.

Dani C, Blanchard J, Piechaczyk M, El Sabouti S, Marty L, Jeanteur P (1984) Extreme instability of myc mRNA in normal and transformed human cells. Proc Natl Acad Sci USA 81:7046-7050.

Dash PK, Karl KA, Colicos MA, Prywes R, Kandel ER (1991) cAMP response element-binding protein is activated by $\mathrm{Ca}^{2+} /$ calmodulin as well as cAMP-dependent protein kinase. Proc Natl Acad Sci USA 88:5061-5065.

de los Frailes MT, Cacicedo L, Lorenzo MJ, Fernández G, SánchezFranco F (1988) Thyroid hormone action on biosynthesis of somatostatin by fetal rat brain cells in culture. Endocrinology 123:898904.

de los Frailes MT, Cacicedo L, Lorcnzo MJ, Sánchez-Franco F (1989) Divergent effects of acute depolarization on somatostatin release and protein synthesis in cultured fetal and neonatal rat brain cells. J Neurochem 52:1333-1339.

de los Failes MT, Sánchez-Franco F, Lorenzo MJ, Fernández Vázquez $G$, Cacicedo L (1990) Depolarizing influences regulate somatostatin synthesis and processing in cultured cerebral cortical cells. Regul Pept 27:97-105.
Eisenstein RS, Rosen JM (1988) Both cell substratum regulation and hormonal regulation of milk protein gene expression are exerted primarily at the postranscriptional level. Mol Cell Biol 8:3183-3188.

Favaloro J, Treisman R, Kamen R (1980) Transcription maps of polyoma virus-specific RNA. Analysis by two-dimensional nuclease S1 gel mapping. Methods Enzymol 65:718-749.

Goodman RH, Aron DC, Roos BA (1983) Rat pre-pro-somatostatin: structure and processing by microsomal membranes. J Biol Chem 258:5571-5573.

Greenberg ME, Greene LA, Ziff EB (1985) Nerve growth factor and epidermal growth factor induced rapid transient changes in protooncogene transcription in PC12 cells. J Biol Chem 260:14101-14110.

Greenberg ME, Ziff EB, Greene LA (1986) Stimulation of neuronal acetylcholine receptors induces rapid gene transcription. Science 234: 80-83.

Guyette WA, Matusik RJ, Rosen JM (1979) Prolactin-mediated transcriptional and posttranscriptional control of casein gene expression. Cell 17:1013-1019.

Herrin DL, Schmidt GW (1988) Rapid, reversible staining of northern blots prior to hybridization. Biotechniques 6:196-200.

Iversen L, Iversen S, Bloom F, Douglas C, Brown M, Vale W (1978) Calcium-dependent release of somatostatin and neurotensin from rat brain in vitro. Nature 273:161-163.

Kley N, Loeffler JP, Pittius CW, Hollt V (1986) Proenkephalin A gene expression in bovine adrenal chromaffin cells is regulated by changes in electrical activity. EMBO J 5:967-970.

Loeffler JP, Kley N, Pittius CW, Hollt V (1986) Calcium ion and cyclic adenosine $3^{\prime} 5^{\prime}$ monophosphate regulate proopiomelanocortin messenger ribonucleic acid levels in rat intermediate and anterior pituitary lobes. Endocrinology 119:2840-2847.

Lu B, Yokoyama M, Dreytus ChF, Black I (1991) Depolarizing stimuli regulate nerve growth factor gene expression in cultured hippocampal neurons. Proc Natl Acad Sci USA 88:6289-6292.

Maeda K, Frohman L (1980) Release of somatostatin and thyrotropinreleasing hormone from rat hypothalamic fragments in vitro. Endocrinology 106:1837-1842.

Montminy MR, Low MJ, Tapia-Arancibia L, Reichlin S, Mandel G, Goodman RH (1986a) Cyclic AMP regulates somatostatin mRNA accumulation in primary diencephalic cultures and in transfected fibroblast cells. J Neurosci 6:1171-1176.

Montminy MR, Sevarino KA, Wagner JA, Mandel G, Goodman RH (1986b) Identification of a cyclic-AMP-responsive element within the rat somatostatin genc. Proc Natl Acad Sci USA 83:6682-6686.

Morgan JI, Curran T (1986) Role of ion influx in the control of c-fos expression. Nature 322:552-555.

Morris BJ, Feasey KJ, Bruggencate GJ, Herz A, Höllt V (1988) Electrical stimulation in vivo increases the expression of proenkephalin mRNA and decreases the expression of prodynorphin mRNA in rat hippocampal granule cells. Proc Natl Acad Sci USA 85:3226-3230.

Mudge AW, Fischbach GD, Leeman SE (1977) The release of immunoreactive somatostatin and substance $\mathbf{P}$ from sensory neurons in dissociated cell cultures. Soc Neurosci Abstr 3:410.

Nairn AC, Hemmings HC, Greengard P (1985) Protein kinases in the brain. Annu Rev Biochem 54:931-976.

Naranjo J, Mocchetti I, Schwartz JP, Costa E (1986) Permissive effect of dexamethasone on increase of proenkephalin mRNA induced by depolarization of chromaffin cells. Proc Natl Acad Sci USA 83:15131517.

Nishizuka $Y$ (1984) The role of protein kinase $C$ in cell surface signal transduction and tumor promotion. Nature 308:693-698.

Patel YC, Reichlin S (1978) Somatostatin in hypothalamus, extrahypothalamic and peripheral tissues of the rat. Endocrinology 102: 523-530.

Patel Y, Zingg H, Dreifuss J (1977) Calcium-dependent somatostatin secretion from rat neurohypophysis in vitro. Nature 267:852-853.

Reichlin S (1983) Somatostatin. N Engl J Med 309:1556-1563.

Roach A, Adler JE, Black IB (1987) Depolarizing influences regulate preprotachykinin mRNA in sympathetic neurons. Proc Natl Acad Sci USA 84:5078-5081.

Robbins RJ, Landon RM (1985) The effects of neurotensin, vasoactive intestinal polypeptide, and other neuropeptides on the secretion of somatostatin from cerebral-cortical cells. Brain Res 332:161-164.

Saffen DW, Cole AJ, Worley DE, Christy BA, Ryder K, Baraban JM (1988) Convulsant-induced increase in transcription factor messenger RNAs in rat brain. Proc Natl Acad Sci USA 85:7795-7799. 
Sheng M, McFadden G, Greenberg ME (1990) Membrane depolarization and calcium induce $\mathrm{c}$-fos transcription via phosphorylation of transcription factor CREB. Neuron 4:571-582.

Sheng M, Thompson MA, Greenberg ME (1991) CKEB: a Ca ${ }^{2+}$-regulated transcription factor phosphorylated by calmodulin-dependent kinases. Science 252:1427-1430.

Shimatsu A, Kato Y, Matsushita N, Katakami H, Yamaihara N, Imura $\mathrm{H}$ (1982) Effects of glucagon, neurotensin and vasoactive intestinal polypeptide on somatostatin release from perfused rat hypothalamus. Endocrinology 110:2113-2117.

Simonet WS, Ness GC (1989) Post-transcriptional regulation of 3-hydroxy-3-methylglutaryl-CoA reductase mRNA in rat liver. J Biol Chem 264:569-573.

Tapia-Arancibia L, Reichlin S (1985) Vasoactive intestinal polypeptide and PHI stinulate soniatostatin release from rat cerebral-cortical and diencephalic cells in dispersed cell culture. Brain Res 336:62-72.

Van Mguyen T, Kobierski L, Comb M, Hyman SE (1990) The effect of depolarization on expression of the human proenkephalin gene is synergistic with cAMP and dependent upon a cAMP-inducible enhancer. J Neurosci 10:2825-2833.

Vannice JL, Taylor JM, Ringold GM (1984) Glucocorticoid-mediated induction of alpha 1-acid glycoprotein: evidence for hormone-regulated RNA processing. Proc Natl Acad Sci USA 81:4241-4245.

Von Dreden G, Loeffler JP, Grimm G, Hollt V (1988) Influence of calcium ions on proopiomelanocortin mRNA levels in clonal anterior pituitary cells. Neuroendocrinology 47:32-37.

Wakabayashi K, Mijazawa Y, Kando M, Miki N, Demura R, Demura H, Shizume K (1977) Stimulation of immunoreactive somatostatin release from hypothalamic synaptosomes by high potassium and dopamine. Endocrinol Jpn 24:601-604.

Waschek JA, Dave JR, Eskay RL, Eiden LE (1987) Barium distinguishes separate calcium targets for synthesis and sccrction of peptides in neuroendocrine cells. Biochem Biophys Res Commun 146:495501 . 